American Journal of Biochemistry and Biotechnology 1 (3): 125-131, 2005

ISSN 1553-3468

(C) 2005 Science Publications

\title{
Antibacterial and Antioxidant Activities of Banana (Musa, AAA cv. Cavendish) Fruits Peel
}

\author{
Matook Saif Mokbel and Fumio Hashinaga \\ Department of Biochemical Science and Technology, Faculty of Agriculture \\ Kagoshima University, 1-21-24, Korimoto, Kagoshima 890-0065, Japan
}

\begin{abstract}
The fresh green and yellow banana peel of, (Musa, cv. Cavendish) fruits were treated with $70 \%$ acetone, which were partitioned with chloroform $\left(\mathrm{CHCl}_{3}\right)$ and ethyl acetate $(\mathrm{EtOAc})$, sequentially. The antioxidant activities of the extracts were evaluated by using the thiocyanate method, B-carotene bleaching method and 1,1-diphenyl-2-picrylhydrazyl (DPPH) free radical elimination. While, antimicrobial activities of the extracts and isolated components were evaluated using paper disc methods and Minimum Inhibition Concentration (MIC). The EtOAc and water soluble fractions of green peel displayed high antimicrobial and antioxidant activity, respectively. Antioxidant activity of water extracts was comparable to those of synthetic antioxidants such as butylated hydroxyanisole and butylated hydroxytoluene. Among all isolated components $\beta$-sitosterol, malic acid, succinic acid, palmatic acid, 12-hydroxystrearic acid, glycoside, the d-malic and 12-hydroxystrearic acid were the most active against all the Gram-negative and positive bacterial species tested. The MIC of d-malic and succinic acid was varying between $140-750 \mathrm{ppm}$, respectively.
\end{abstract}

Key words: Banana, ß-sitosterol, malic acid, succinic acid, palmatic acid, 12-hydroxystrearic acid, glycoside

\section{INTRODUCTION}

Free sugars, organic acids and amino acids are natural components of many fruits and vegetables and they play important roles in maintaining fruit quality and determining nutritive value ${ }^{[1]}$. During banana repining, the starch converted into reducing sugars and sucrose increasing with ripeness ${ }^{[2]}$. Banana a tropical plant may protect itself from the oxidative stress caused by strong sunshine and high temperature by producing large amounts of antioxidant ${ }^{[3]}$. Banana should be considered to be a good source of natural antioxidant for foods and functional food source against cancer and heart diseas $\mathrm{e}^{[4]}$. Therefore, attention in recent times has been focused on the isolation, characterization and utilization of natural antioxidants, especially growing interest in polyphenols as potential disease preventing agents. As these compounds are predominantly found in most of fruit tissues, it would be worthwhile investigating the nature of polyphenols that are present in banana peel. Fruits and vegetables however, contain many different antioxidant and antimicrobial components. The majority of the antioxidant capacity of a fruit or vegetable may be from compounds such as other vitamin $C$, vitamin $E$ or $\beta$-carotene. Bananas are one of the most popular fruits on the world and it well be known that fruits contain various antioxidants compounds such as gallocatechin ${ }^{[4]}$ and dopamine ${ }^{[3]}$. Since the banana fruits are widely available, they been used as food without apparent toxic effect. The peel could be a potential source of antioxidant and antimicrobial activities.

The present investigation was undertaken to evaluate the antioxidant and antibacterial power of banana fruit peel and to identify the responsible compounds for those activities. Also, in the present communication we studied the components isolated from green peel and determined their activities.

\section{MATERIALS AND METHODS}

Plant material and extraction methods: Banana (Musa, AAA cv. Cavendish) fruits were purchased in Kagoshima city at green stage without any ethylene treatment and stored at $20^{\circ} \mathrm{C}$ for $24 \mathrm{hr}$ before being extracted. Color (a value) was measured by Chroma meter (model CR-200; Minolta, Japan) as described in previous studies $^{[5]}$.

Extraction procedures: The peel tissues of fresh banana fruit $(300 \mathrm{~g})$ at green with a trace of yellow stage were heated in $1 \mathrm{~L}$ of distilled water for $2 \mathrm{~min}$. The peel was homogenized with $70 \%$ acetone twice at room temperature in an electric blender. The combined extracts of $70 \%$ acetone extracts were then filtered and concentrated to $200 \mathrm{~mL}$. This aqueous extract was partitioned into a $\mathrm{CHCl}_{3}$ and water, using electric shaker and then extracted with aqueous saturated ethyl

Corresponding Author: Matook Saif Mokbel, Department of Biochemical Science and Technology, Faculty of Agriculture, Kagoshima University, 1-21-24, Korimoto, Kagoshima 890-0065, Japan, Tel: + 81-99-285-8639 
acetate. The dry matters were $0.73,1.2 \mathrm{~g}$ and $9 \mathrm{~g}$, respectively. The antimicrobial and antioxidant activity of $\mathrm{CHCl}_{3}, \mathrm{EtOAc}$ and water extracts were measured. The yellow banana peel was treated similarly. The active $70 \%$ acetone extracts were subjected to silica gel 60 eluting by step wire with mixtures of different solvents (hexane:EtOAc:MeOH) respectively. The resulting fractions were examined by silica gel 60 thin-layer chromatography (TLC) and those fractions with similar TLC profiles were combined to give total fractions.

Determination of antioxidant activity using free radical scavenging activity (DPPH): The inhibition of free radical scavenging activity by dry matters of banana fruit tissues was measured as following: A 0.5 $\mathrm{mM}$ solution of DPPH (1,1-diphenyl-2- picrylhydrazol) in methanol and $0.05 \mathrm{M}$ acetate buffer (5.5) $\mathrm{pH}$ was prepared. An aliquot of $0.1 \mathrm{~mL}$ (at concentrations $0.5-1$ $\mathrm{mg} \mathrm{mL} \mathrm{mL}^{-1}$ ) of the extract was added to $2 \mathrm{~mL}$ acetate buffer and $1.9 \mathrm{~mL}$ methanol $+1 \mathrm{~mL}$ DPPH solution. Blank contains $2 \mathrm{~mL}$ acetate buffers, $1.9 \mathrm{~mL}$ methanol and $0.1 \mathrm{~mL}$ of the extract. While the control contained 2 $\mathrm{mL}$ acetate buffer, $1 \mathrm{~mL}$ DPPH and $2 \mathrm{~mL}$ methanol. The mixture was shaken immediately after adding DPPH and allowed to stand at room temperature in a dark and the decrease in absorbance at $517 \mathrm{~nm}$ was measured after $30 \mathrm{~min}$ until the reaction reached a plateau. These experiments were run in duplicate. The inhibitory percentage of DPPH was calculated according to Shyu et al. ${ }^{[6]}$ as following: Scavenging effect $(\%)=\left[\left(\mathrm{A}_{\mathrm{o}}-\left(\mathrm{A}-\mathrm{A}_{\mathrm{b}}\right)\right) / \mathrm{A}_{\mathrm{o}}\right] \times 100 \%$, where: $\mathrm{A}_{\mathrm{o}}: \mathrm{A}_{517}$ of DPPH without sample (control); $A: A_{517}$ of sample and $\mathrm{DPPH}$; and $\mathrm{A}_{\mathrm{b}}: \mathrm{A}_{517}$ of sample without $\mathrm{DPPH}$ (blank).

Determination of antioxidant activity using B-carotene linoleate model system: Antioxidant activity was measured using the methods of Jayaprakasha et al. ${ }^{[7]}$ with slight modification. A 3.34 $\mathrm{mg}$ of $\beta$-carotene in chloroform solution $(1 \mathrm{~mL})$ and the chloroform was removed at $40^{\circ} \mathrm{C}$ under vacuum using a rotary evaporator. Thereafter, $40 \mathrm{mg}$ of linoleic acid and $400 \mathrm{mg}$ of Tween-20 were added and mixed well. The resulting mixture was immediately diluted with 5-10 mL of triple distilled water and was mixed well. The emulsion was further made up to $100 \mathrm{~mL}$ with $0.01 \mathrm{M}$ hydrogen peroxide $\left(\mathrm{H}_{2} \mathrm{O}_{2}\right)$. Aliquots $(2 \mathrm{~mL})$ of this emulsion were transferred into different test tubs containing $0.1 \mathrm{~mL}$ of test samples in methanol. In this experiment BHA was used for comparative purposes. A control containing $0.2 \mathrm{~mL}$ of ethanol and $4 \mathrm{~mL}$ of the above emulsion was prepared. The tubes were placed in a water bath at $50^{\circ} \mathrm{C}$. Absorbances of all the samples at $470 \mathrm{~nm}$ were taken at zero time and every $20 \mathrm{~min}$ until the color of B-carotene disappeared in the control reaction. The blank prepared as above mentioned, but without ß-carotene.

Antioxidant assay using ferric thiocyanate methods: A mixture of a $2 \mathrm{~mL}$ sample in $99.5 \%$ ethanol, 2.052 $\mathrm{mL}$ of $2.51 \%$ linoleic acid in $99.5 \%$ ethanol, $4 \mathrm{~mL}$ of $0.05 \mathrm{M}$ phosphate buffer (PH 7.0) and $1.948 \mathrm{~mL}$ of water was placed in a vial with a screw cap and placed in an oven at $60^{\circ} \mathrm{C}$ in the dark. To $0.1 \mathrm{~mL}$ of this sample solution $9.7 \mathrm{~mL}$ of $75 \%$ ethanol and $0.1 \mathrm{~mL}$ of $30 \%$ ammonium thiocyanate was added. After the addition of $0.1 \mathrm{~mL}$ of $2 \times 10^{-2} \mathrm{M}$ ferrous chloride in $3.5 \%$ hydrochloric acid to the reaction mixture, the absorbance of the red color developed was measured in $3 \mathrm{~min}$ at $500 \mathrm{~nm}^{[8]}$.

Antimicrobial assay: Antimicrobial assay was measured using the methods of Mokbel and Hashinaga $^{[9]}$. Five species of bacteria were used: Bacillus cereus IFO 13597, Salmonella enteritidis IFO 3313, Escherichia coli IFO 13168, Bacillus subtilis IFO 3009, Staphylococcus aureus IFO 3761.

The bacteria stock culture media were maintained on nutrient hard agar (peptone $1 \mathrm{~g}$, meat extract $0.5 \mathrm{~g}$, sodium chloride $0.25 \mathrm{~g}$ and agar $1 \mathrm{~g} 100 \mathrm{~mL}^{-1} \mathrm{H}_{2} \mathrm{O}$ ) at $4^{\circ} \mathrm{C}$. The bacterial culture medium was prepared as following, nutrient broth (peptone $0.5 \mathrm{~g}$, meat extracts

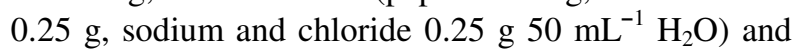
soft agar medium (peptone $0.5 \mathrm{~g}$, meat extracts $0.25 \mathrm{~g}$, sodium chloride $0.125 \mathrm{~g}$ and agar $0.2 \mathrm{~g} 50 \mathrm{~mL}^{-1} \mathrm{H}_{2} \mathrm{O}$ ) adjusted to $\mathrm{pH} 6.6$ and autoclaved at $121^{\circ} \mathrm{C}$ for $20 \mathrm{~min}$.

To determine the antibacterial activity the microorganisms were cultured in nutrient broth at $36^{\circ} \mathrm{C}$ overnight. Three-five $\mu \mathrm{L}$ of the inocula (spores) was added to $3.5 \mathrm{~mL}$ soft nutrient agar and well shaken. The soft nutrient agar was then added on a Petri dish containing $15 \mathrm{~mL}$ hard agar. Filter paper discs $(6 \mathrm{~mm}$ in diameter), were impregnated with different concentrations $\left(0.1\right.$ to $\left.1 \mathrm{mg} \operatorname{discs}^{-1}\right)$ and allowed to dry completely for 10-15 min and then evenly placed on the surface of previously inoculated agar. The Petri dishes were incubated at $36^{\circ} \mathrm{C}$ for $24 \mathrm{hr}$. Chloramphenicol was used as a positive control.

Determination of MIC: The minimum inhibitory concentrations (MIC) were defined as the lowest concentration (ppm) of the extract in agar plates showing no visible bacterial growth. The soft nutrient agar was then added onto a Petri dish containing $15 \mathrm{~mL}$ hard agar as mentioned above. The samples were dissolved in chloroform and/or methanol. The solutions were then individually added at different concentrations from ( 0 (control) to $\left.1 \mathrm{mg} \mathrm{mL}^{-1}\right)$ to soft agar and mixed 


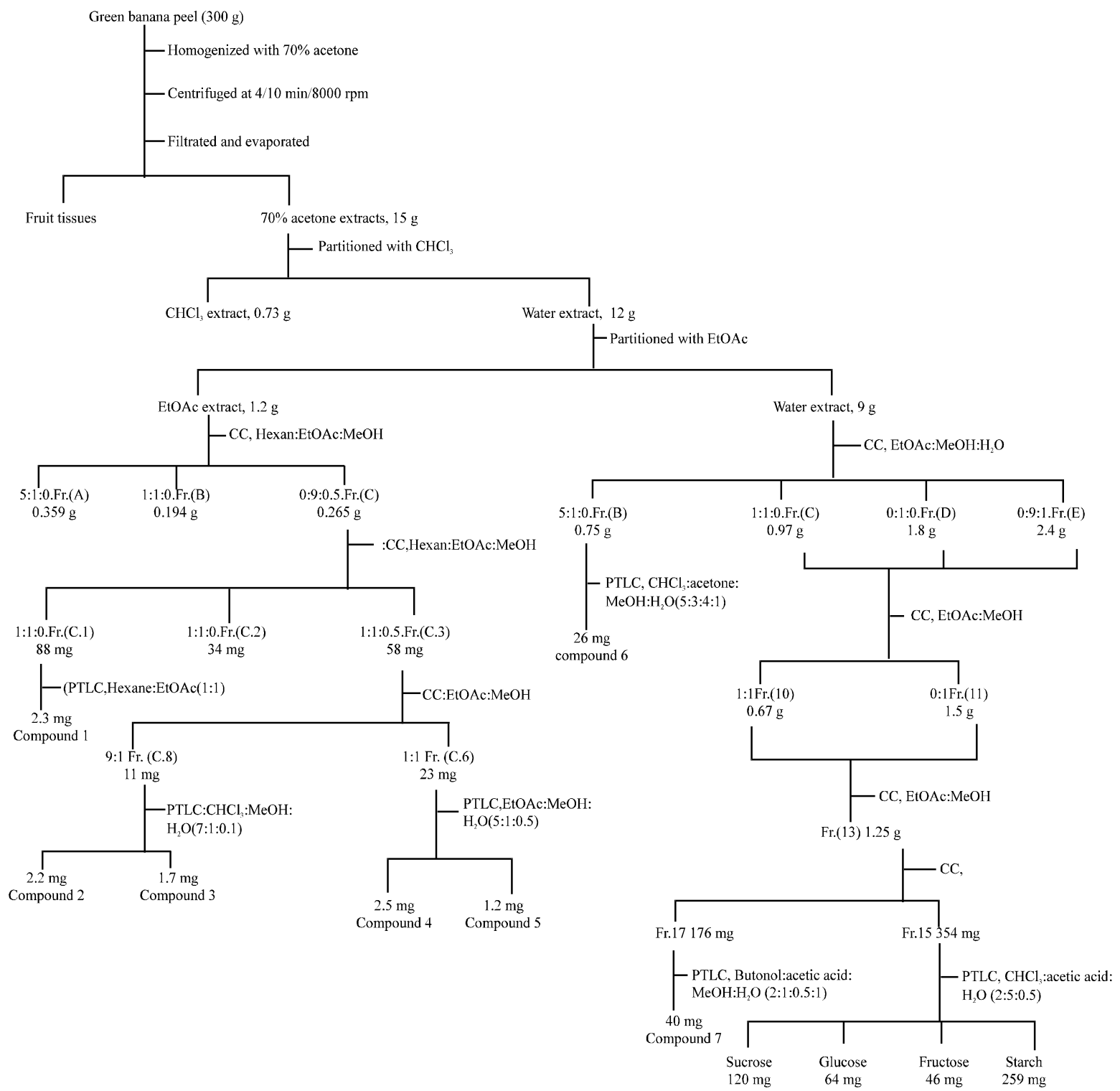

Fig. 1: Separation scheme of the antioxidant and antimicrobial substance from green banana peel

well before being poured into sterile Petri dishes containing $15 \mathrm{~mL}$ hard agar. The cultures $(5 \mu \mathrm{L})$ were taken from nutrient broth and added to three places on the medium surface and incubated at $37^{\circ} \mathrm{C}$.

Thin-layer chromatography analysis (TLC) analysis: TLC analysis for crude extracts or silica gel column chromatography fractions was performed on aluminium sheets $(20 \times 20 \mathrm{~cm})$ of silica gel $60 \mathrm{~F}_{254}$ plate which were developed with appropriate solvents for each sample such as $\left(\mathrm{CHCl}_{3}: \mathrm{MeOH}\right.$ :hexane (5:1:0.5), $\mathrm{CHCl}_{3}: \mathrm{MeOH}: \mathrm{H}_{2} \mathrm{O}$ (5:1:0.5), $\mathrm{CHCl}_{3}:$ acetone:MeOH: $\mathrm{H}_{2} \mathrm{O} \quad(5: 3: 4: 1)$ or 1-butanol:acetic acid:MeOH: $\mathrm{H}_{2} \mathrm{O}$ $(2: 1: 0.5: 1))$. The resulting bands were located using UV-light and $10 \%$ sulfuric acid spray followed by heating in the oven for $5-10 \mathrm{~min}$ at $120^{\circ} \mathrm{C}$.
General procedures: Nuclear Magnetic Resonance (NMR) spectra were recorded on a JEOL FX-400 spectrometer operated at $400 \mathrm{MHz}$ for ${ }^{1} \mathrm{H}-\mathrm{NMR}$ and at $100 \mathrm{MHz}$ for ${ }^{13} \mathrm{C}$-NMR. The spectra were observed on $\mathrm{CDCl}_{3}$ for low polarity compounds and deuterium oxide $\left(\mathrm{D}_{2} \mathrm{O}\right)$ for high polarity compounds containing TMS as an internal standard.

Gas chromatography/ mss spectrometry: Molecular weight was determined using gas chromatography (Thermo Finnign Polaris Q) equipped with an EI ion source coupled to an MS (Polaris Q). Helium was used as gas carrier, and the injector temperature was kept at $250^{\circ} \mathrm{C}$. 


\section{RESULTS AND DISCUSSION}

Chromatographic separation: Isolation and identifications of ethyl acetate extract $(1.2 \mathrm{~g})$ of green banana peel was carried out on a silica gel column. The column chromatography was eluted with

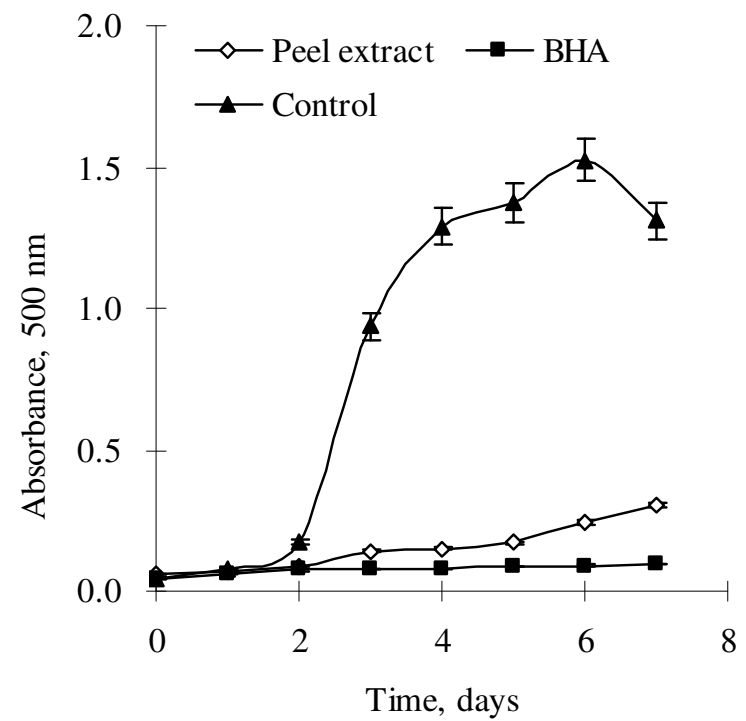

Fig. 2: Antioxidant activities of $70 \%$ acetone extracts from green banana peel as measured using the thiocyanate method

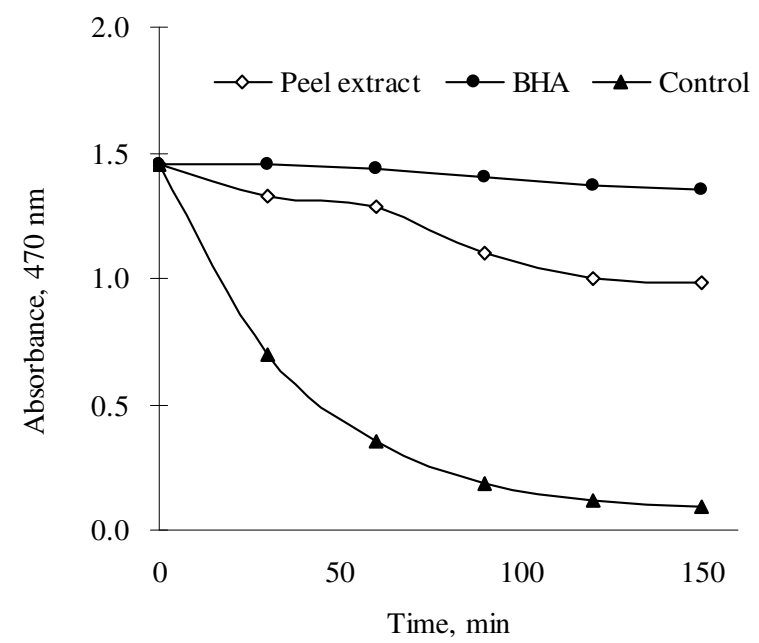

Fig. 3: Antioxidant activities of $70 \%$ acetone extracts from green banana peel tissues as measured by B-carotene bleaching method

hexane:EtOAc:MeOH (Fig. 1) with an increasing amount of EtOAc: $\mathrm{MeOH}$ gradually to yield three frs. 5:1:0, 1:1:0 and 0:9:0.5 (A, B and C). Among them, Fr. $\mathrm{C}$ was recorded high antimicrobial activities and was further chromatographed on silica gel column and eluted with hexane:EtOAc: $\mathrm{MeOH}$, yielding two active frs. 1:1:0 and 0:1:0.5 (C.1 and C.3). Fr. (C.1) was developed with $\mathrm{CHCl}_{3}: \mathrm{MeOH}(1: 1)$ to yield $(2.3 \mathrm{mg}$,
$191 \mathrm{mg} 100 \mathrm{~g}^{-1}$ dry wt) $\beta$-sitosterol (known compound 1). Fr. (C.3) was further chromatographed on silica gel column and eluted with EtOAc: $\mathrm{MeOH}$, yielding two active fractions 9:1 and 1:1 (C.6 and C. 8). Fr. (C.8) was further subjected to preparative TLC (PTLC) plates $(20 \times 20 \mathrm{~cm})$ of silica gel $60 \mathrm{~F}_{254}$ Merch Ltd. Japan using $\mathrm{CHCl}_{3}: \mathrm{MeOH}: \mathrm{H}_{2} \mathrm{O}(7: 1: 0.1)$ as a solvent system to yield (2.2 mg, $183 \mathrm{mg} 100 \mathrm{~g}^{-1}$ dry wt) Palmitic acid

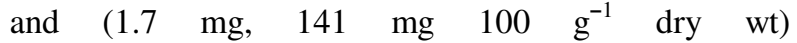
12-hydroxystrearic acid (known compounds 2 and 3), respectively. Fr. (C.6) was further subjected to preparative TLC using $\mathrm{CHCl}_{3}: \mathrm{MeOH}_{2} \mathrm{H}_{2} \mathrm{O}$ (5:1:0.1) to yield two active compounds $\left(2.5 \mathrm{mg}, 208 \mathrm{mg}^{-100 \mathrm{~g}^{-1}}\right.$ dry wt) malic acid and (1.2 mg, $100 \mathrm{mg} 100 \mathrm{~g}^{-1}$ dry wt) succinic acid (known compounds 4 and 5), respectively. Other fractions produced spots containing either weak antimicrobial and antioxidative compounds or low concentration. Those compounds were identified by comparison of TLC behavior, ${ }^{1} \mathrm{H}-\mathrm{NMR}$ and ${ }^{13} \mathrm{C}-\mathrm{NMR}$ spectra with those of authentic samples.

Water extract $(9 \mathrm{~g})$ was chromatographed on a silica gel column using an eluant of EtOAc: $\mathrm{MeOH}$ : water with an increasing amount of $\mathrm{MeOH}$ :water gradually to yield five fractions 9:1:0, 5:1:0, 1:1:0, 0:1:0 and 0:9:1 (A, B, C, D and E). Among them, three active fractions $\mathrm{B}, \mathrm{C}$ and $\mathrm{D}$ were recorded high antioxidant activity. Fraction (B) was further loaded to PTLC using $\mathrm{CHCl}_{3}$ :acetone: $\mathrm{MeOH}: \mathrm{H}_{2} \mathrm{O}$ (5:3:4:1) to yield (26 mg, $288 \mathrm{mg} 100 \mathrm{~g}^{-1}$ dry wt) glycoside component (6), While, other fraction has strong antioxidant activity as measured by DPPH methods which purified using PTLC with butanol:acitic

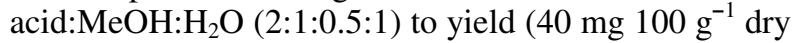
wt) monosaccharide compound (7). Those fractions $(\mathrm{C}$ and D) were combined according to TLC monitoring. The active fraction was further chromatographed on a silica gel column and eluted with EtOAc:MeOH 1:1 and $0: 1$ yielding Fr. (13) total soluble sugars $(1.25 \mathrm{~g}$,

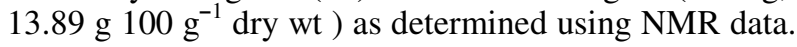
This fraction was further subjected to silica gel column and eluted with EtOAc: $\mathrm{MeOH}(1: 1$ to $0: 1)$ respectively several time. Thereafter, purified by PTLC to yield two fractions according to TLC aluminum monitoring system one fraction has no antioxidant activities of total soluble sugars (sucrose, glucose and fructose).

Antioxidant activities: The antioxidant effects of crude extracts from green banana and yellow peel were investigated and the results indicated that the extract of green peel recorded more significant activities than that of yellow peel at other solvents extracts. However, our investigations for antimicrobial and antioxidant activities were focused in water and ethyl acetate extracts of green peel. Green banana peel displayed high antioxidant activity as measured by $\beta$-carotene bleaching method, DPPH free radical and linoleic acid emulsion. The oxidative activity of linoleic acid was markedly inhibited by extracts as shown in Fig. 2. The BHA at $0.1 \mathrm{mg} \mathrm{mL}^{-1}$ as same as green banana extracts 
Am. J. Biochem. \& Biotechnol., 1 (3): 125-131, 2005

Table 1: DPPH scavenging activity and yield of antioxidant constituents of banana peel tissues

\begin{tabular}{|c|c|c|c|c|c|c|}
\hline \multirow{2}{*}{$\begin{array}{l}\text { Banana } \\
\text { fruit tissues }\end{array}$} & \multicolumn{3}{|c|}{ Crude extract } & \multicolumn{3}{|c|}{ Chromatograph of water extracts of green peel } \\
\hline & Solvent & $\begin{array}{l}\text { Yield } \\
(\mathrm{g})\end{array}$ & $\begin{array}{r}\text { Activities } \\
\text { DPPH (\%) }\end{array}$ & $\begin{array}{l}\text { Silica gel } \\
\text { Frs. No. }\end{array}$ & $\begin{array}{c}\text { Yield } \\
(\mathrm{g})\end{array}$ & $\begin{array}{l}\text { Activities } \\
\text { DPPH }(\%)\end{array}$ \\
\hline \multirow[t]{3}{*}{ Green peel } & $\mathrm{CHCl}_{3}$ & 0.73 & $26.2 \pm 0.4$ & EtOAc:MeOH (9:1) & 0.47 & $18.2 \pm 0.5$ \\
\hline & EtOAc & 1.2 & $52.1 \pm 0.2$ & EtOAc:MeOH (5:1) & 0.75 & $72.6 \pm 0.4$ \\
\hline & $\mathrm{H}_{2} \mathrm{O}$ & 9.2 & $75.3 \pm 0.6$ & EtOAc:MeOH (1:1) & 0.97 & $81.4 \pm 0.1$ \\
\hline \multirow[t]{3}{*}{ Yellow peel } & $\mathrm{CHCl}_{3}$ & 0.09 & $8.7 \pm 0.3$ & EtOAc:MeOH $(0: 1)$ & 1.8 & $80.6 \pm 0.3$ \\
\hline & EtOAc & 0.12 & $43.7 \pm 0.5$ & $\mathrm{MeOH}: \mathrm{H}_{2} \mathrm{O} \quad(9: 1)$ & 2.4 & $73.5 \pm 0.6$ \\
\hline & $\mathrm{H}_{2} \mathrm{O}$ & 10.3 & $9.8 \pm 0.2$ & & & \\
\hline BHA & & & $82.3 \pm 0.1$ & & & $82.3 \pm 0.1$ \\
\hline BHT & & & $81.8 \pm 0.3$ & & & $81.8 \pm 0.3$ \\
\hline
\end{tabular}

Homogenized $300 \mathrm{~g}$ banana green and yellow peel in 1L 70\% acetone, filtrated, concentrated and partitioned with EtOAc-water (1:1). *Water extracts $9 \mathrm{~g}$ was fractionated using slica gel column chromatography and eluted with EtOAc:MeOH.

Table 2: Antibacterial activity of the various extracts of banana fruit tissues using disc diffusion assay

\begin{tabular}{|c|c|c|c|c|c|c|}
\hline \multirow[b]{3}{*}{ Bacteria } & \multicolumn{6}{|c|}{ Fruit tissue extracts/mean length of inhibition zones $(\mathrm{mm}) \pm$ S.D } \\
\hline & \multicolumn{3}{|c|}{ Green peel } & \multicolumn{3}{|c|}{ Yellow peel } \\
\hline & $\mathrm{CHCl}_{3}$ & EtOAc & Water extracts & $\mathrm{CHCl}_{3}$ & EtOAc & Water extracts \\
\hline \multicolumn{7}{|l|}{ Gram positive bacteria } \\
\hline Staphylococcus aureus & 0 & $12 \pm 0.4$ & 0 & 0 & $3 \pm 0.1$ & 0 \\
\hline Bacillus subtilis & 0 & $10 \pm 0.3$ & 0 & 0 & $3 \pm 0.2$ & 0 \\
\hline Bacillus cereus & 0 & $11 \pm 0.1$ & 0 & 0 & $2 \pm 0.4$ & 0 \\
\hline \multicolumn{7}{|l|}{ Gram negative bacteria } \\
\hline Salmonella enteritidis & 0 & $10 \pm 0.2$ & 0 & 0 & $1 \pm 0.0$ & 0 \\
\hline Escherichia coli & 0 & $9 \pm 0.2$ & 0 & 0 & $2 \pm 0.2$ & 0 \\
\hline
\end{tabular}

Values are means \pm S.D of 9 paper disc for each three replication were used.

Sterile paper disc (6 mm diameter) was impregnated with fruit tissue extracts $\left(1 \mathrm{mg} \mathrm{disc}^{-1}\right)$.

was included as positive control for the hydrophilic antioxidant. The results showed that the inhibitory activity of $70 \%$ acetone extracts of green banana peel using thiocyanate method at concentration of $0.5 \mathrm{mg}$ $\mathrm{mL}^{-1}$ closed to the synthetic antioxidant reagent of BHA at $0.1 \mathrm{mg} \mathrm{mL}^{-1}$. The absorbance of control has increased in 6 days and decreased thereafter due to oxidation of linoleic acid generating linoleic acid hydroperoxides, which decompose too many secondary oxidation products in agreement with Jayaprakasha et $a l .{ }^{[7]}$. In the linoleic acid system $\beta$-carotene bleaching method, oxidation of linoleic acid was significantly inhibited by polar fraction of $70 \%$ acetone extract (Fig. 3 ). Increasing the polarity throughout the extracts exhibited stronger activity, indicating that polyphenols or flavanones and flavonoids may also play important roles in the activities. These results were in agreement with Tepe et al. ${ }^{[10]}$. In all cases, the control without addition of antioxidant oxidized more rapidly, while the sample elicited inhibition of bleaching of $B$-carotene. Free radical scavenging capacities of the extracts, measured by DPPH assay, are shown in Table 1 . The free radical scavenging activity of aqueous acetone extract was superior to all other extracts, followed by EtOAc extracts and yellow banana peel showed low antioxidant activity. The water extracts were eluted in silica gel column for fractionation and those fractions displayed significant antioxidant activity as measured by DPPH free radical.

Antimicrobial activities: EtOAc extract of green banana peel recorded significant antimicrobial activities, while yellow peel extracts recorded low activity and no activity was recorded to $\mathrm{CHCl}_{3}$ and water extracts as measured by paper disk methods (Table 2). The MIC was measured after $48 \mathrm{~h}$ of incubation at $36^{\circ} \mathrm{C}$.

As shown in Table 3, the MIC of B-sitosterol, palmitic acid, malic acid and succinic acid was tested against $S$. aureus, B. subtilis, B. cereus, S. enteritidis and $E$. coli. B-sitosterol, malic acid and succinic acid were active against all tested the Gram-negative and Gram-positive bacterial species, while palmitic acid was insignificant against all tested the bacteria species. The minimum inhibitory concentration (MIC) of ß-sitosterol, Malic acid and succinic acid varying between 140-750 ppm, respectively. These data indicated that malic acid exhibited strong antibacterial activity compared to $\beta$-sitosterol, succinic acid and palmaitic acid. While, 12-hydroxystrearic acid recorded antimicrobial activity as measured by paper disk methods but didn't measure for MIC. This study clearly indicated that isolated compound inhibited the growth of food poisoning bacteria in vivo. 
Table 3: Antibacterial activity of the compounds isolated from green banana peel using agar disc diffusion and MIC methods

\begin{tabular}{|c|c|c|c|c|c|c|c|c|c|c|c|c|}
\hline \multirow[b]{3}{*}{ Microorganisms } & \multicolumn{8}{|c|}{ Isolated compounds } & \multicolumn{4}{|c|}{ Standard antibiotics } \\
\hline & \multicolumn{2}{|c|}{$\beta$-sitosterol } & \multicolumn{2}{|c|}{ 12-hydroxystrearic acid } & \multicolumn{2}{|c|}{ Palmitic acid } & \multicolumn{2}{|c|}{ d-Malic acid } & \multicolumn{2}{|c|}{ Succinic acid } & \multicolumn{2}{|c|}{ Chloramphenicol } \\
\hline & $\mathrm{DD}^{\mathrm{a}}$ & $\mathrm{MIC}^{\mathrm{b}}$ & $\mathrm{DD}^{\mathrm{a}}$ & $\mathrm{MIC}^{\mathrm{b}}$ & $\mathrm{DD}^{\mathrm{a}}$ & $\mathrm{MIC}^{\mathrm{b}}$ & $\mathrm{DD}^{\mathrm{a}}$ & $\mathrm{MIC}^{\mathrm{b}}$ & $\mathrm{DD}^{\mathrm{a}}$ & $\mathrm{MIC}^{\mathrm{b}}$ & $\mathrm{DD}^{\mathrm{a}}$ & $\mathrm{MIC}^{\mathrm{b}}$ \\
\hline \multicolumn{13}{|l|}{ Gram positive bacteria } \\
\hline Staphylococcus aureus & $7.1 \pm 0.3$ & 330 & $10 \pm 0.5$ & NT & $>1000$ & $>1000$ & $11 \pm 0.6$ & 180 & $5.1 \pm 0.3$ & 620 & $25 \pm 0.5$ & 5.5 \\
\hline Bacillus subtilis & $6.2 \pm 0.2$ & 270 & $11 \pm 0.3$ & NT & $>1000$ & $>1000$ & $10 \pm 0.9$ & 160 & $4.8 \pm 0.2$ & 580 & $24 \pm 0.3$ & 5.5 \\
\hline Bacillus cereus & $6.7 \pm 0.4$ & 250 & $12 \pm 0.2$ & NT & $>1000$ & $>1000$ & $11 \pm 0.2$ & 140 & $5.7 \pm 0.4$ & 650 & $26 \pm 0.7$ & 5.5 \\
\hline \multicolumn{13}{|l|}{ Gram negative bacteria } \\
\hline Salmonella enteritidis & $5.8 \pm 0.3$ & 350 & $9 \pm 0.1$ & NT & $>1000$ & $>1000$ & $9 \pm 0.1$ & 280 & $4.7 \pm 0.3$ & 730 & $20 \pm 0.5$ & 5.5 \\
\hline Escherichia coli & $6.8 \pm 0.4$ & 300 & $8 \pm 0.4$ & NT & $>1000$ & $>1000$ & $8 \pm 0.4$ & 420 & $4.1 \pm 0.4$ & 750 & $19 \pm 0.5$ & 5.5 \\
\hline
\end{tabular}

Fruit repining: It has been reported by Mokbel and Hashinaga $^{[5]}$ that the decay and rotting during banana repining increased, especially when these fruits were stored in plastic film due to decrease malic acid and succinic acid with degree of banana fruit repining. While those fruits stored under high carbon dioxide extended the shelf life of banana fruits, which may be related to increasing of malic acid and succinic acid. The banana fruit at green stage less decay also may due to high concentrations of malic acid, succinic acid and others compounds and the decay increased with decreasing those compounds during repining. According to previous study a climacteric fruit like peach, has been shown that there is an accumulation of malic acid in the fruit during growth and ripening and that fruit maturity is more advanced when the malic acid concentration is higher ${ }^{[11]}$. According to our previous studies (Mokbel and Hashinaga ${ }^{[5]}$ the climacteric peak of banana fruits stored at $20^{\circ} \mathrm{C}$ happened between 5-7 days of storage, thereafter the respirations, ethanol productions and the conversion of total sugar content increased immediately. Holcroft and $\operatorname{Kader}^{[12]}$ found that, the concentration of malic acid in strawberry fruit decreased, increasing succinic acid during fruits ripening and also reported that succinic acid concentrations increased during storage under 20 $\mathrm{kPa} \mathrm{CO}_{2}$. Increasing $\mathrm{CO}_{2}$ may connect to increasing succinic acid, which extend the shelf life of banana fruits during storage due to inhibition of fungal growth in vivo ${ }^{[13]}$. Beaudry et al. ${ }^{[14]}$ reported that sucrose increased very rapidly after the peak in ethylene synthesis. The amount of reducing sugars and sucrose increased and the amount of starch decreased drastically with ripening.

Fractose, glucose and sucrose were the major soluble sugars in water fractions of green banana peel as determined using NMR. The doublet at $5.42 \mathrm{ppm}$ is due to H-3' of sucrose; the triplet at $4.05 \mathrm{ppm}$ is due to $\mathrm{H}-4$ ' of sucrose; the resonance signals at 3.89, 3.82, $3.77,3.68$ and $3.56 \mathrm{ppm}$ have been assigned to sucrose too. The doublets at 5.24 and $4.65 \mathrm{ppm}$ are due to the anomeric protons of glucose, $\alpha$-glucose $\mathrm{H}-1$ and beta-glucose $\mathrm{H}-1$, respectively; the triplet at $3.25 \mathrm{ppm}$ is due to the $\beta$-glucose $\mathrm{H}-2$. The doublet at $4.12 \mathrm{ppm}$ is the only resonance signal clearly assigned to fructose. The resonance signals in the region from $3.98 \mathrm{ppm}$ are mainly due to overlapping resonances of ring protons of sucrose, fructose and glucose. This results corresponding with ${ }^{1} \mathrm{H}-\mathrm{NMR}$ data of Raffo et al. ${ }^{[15]}$. However, sucrose, fructose and glucose recorded low antioxidant activities as measured by DPPH free radical. Glycoside and monosaccharide components isolated (compound 6 and 7) had a higher antioxidant activity than sucrose, glucose, fructose or control at concentration $100 \mathrm{mg} \mathrm{mL}^{-1}$.

\section{CONCLUSION}

Ethyl acetate and water soluble fractions of green banana peel displayed high antimicrobial and antioxidant activity. Most of the compounds isolated from green peel B-sitosterol, malic acid, 12-hydroxystrearic acid and succinic acid, which showed significant antibacterial activities and low antioxidant activities. While, those compounds isolated from water soluble extracts glycoside and monosaccharide components displayed significant antioxidant and low antimicrobial activity.

\section{REFERENCES}

1. Ashoor, S.H. and J.M. Knox, 1982. Determination of organic acids in foods by high-perfoprmance liquid chromatography. J. Chrom., 299: 288-292.

2. Lii, C.Y., Chang, S. and Y.L. Young, 1982. Investigation of the physical and chemical properties of banana starches. J. Food Sci., 47: 1493-1497. 
3. Kanazawa, K and H. Sakakibara, 2000. High content of dopamine, a strong antioxidant, in Cavendish banana. J.Agricul. and Food Chem. 48: 844-848.

4. Someya, S., Y. Yoshiki and K. Okubo, 2002. Antioxidant compounds from bananas (Musa Cavendish). Food Chem., 79: 351-354.

5. Mokbel, M.S. and F. Hashinaga, 2004a. Effect of heat, calcium chloride and modified atmosphere on the shelf life of banana fruits. Food Preserv. Sci., 30: 179-184.

6. Shyu, Y.S and L.S. Hwang, 2002. Antioxidant activity of the crude extracts of lignan glycosides fromunroasted Burma black sesame meal. Food Research Intl., 35: 357-365.

7. Jayaprakasha, G.K., R.P. Singh and K.K. Sakariah, 2001. Antioxidant activity of grape seed (Vitis vinifera) extracts on peroxidation models in vitro. Food Chem., 73: 285-290.

8. Inatani, R., N. Nakatani and Fuwa, 1983. Antioxidative effect of the constituents of Rosemary (Rosmarinus officinalis L.) and their derivatives. Agric. Biol. Chem., 47: 521-528.

9. Mokbel, M.S. and F. Hashinaga, 2005. Evaluation of the antimicrobial activity of extract from buntan (Citrus grandis Osbeck) fruit peel. Pak. J. Biol. Sci., 8: 1090-1095.
10. Tepe, B., D. Daferera, A. Sokmen, M. Sokmen and M. Polissiou, 2005. Antimicrobial and antioxidant activities of the essential oil and various extracts of Salvia tomentosa Miller (Lamiaceae). Food Chem., 90: 333-340.

11. Liverani, A. and A. Cangini, 1991. Ethylene evolution and changes in carbohydrates and organic acid during maturation of two white and two yellow fleshed peach cultivars. Adv. Hortic. Sci., 5: 59-63.

12. Holcroft, D.M. and A.A. Kader, 1999. Controlled atmosphere-induced changes $\mathrm{pH}$ and organic acid metabolism may affect color of stored strawberry fruit. Postharvest Biol. Technol., 17: 19-32.

13. Mokbel, M.S. and F. Hashinaga, 2004b. Effect of modified atmospheres on selected postharvest pathogens. Pak. J. Biol. Sci., 7: 1993-1995.

14. Beaudry, R.M., S.C.C. Black and S.J. Kays, 1989. Banana ripening: Implications of changes in glycolytic intermediate concentrations, glycolytic and gluconegenic carbon flux and fructose 2, 6-Bisphosphate concentration. Plant physiol., 91: 1436-1444.

15. Roaffo, A., R. Gianferri, R. Barbieri and E. Brosio, 2005. Ripening of banana fruit monitored by water relaxation and diffusion ${ }^{1} \mathrm{H}-\mathrm{NMR}$ measurements. Food Chem., 89: 149-158. 